\title{
A Study of Extent of Usage of Financial Inclusion Services in Punjab
}

\author{
Dr. kanwaljit Kaur \\ Associate Prof in Economics, SGGS College, Chandigarh \\ Kkanwaljit27@gmail.com \\ Sarbjeet Kaur \\ Assistant Professor in Economics, Government College of Commerce and Business Administration, Sector-50 \\ Chandigarh \\ Johalthjb24@gmail.com
}

\begin{abstract}
The study focused on evaluating the extent of usage of different financial services. The study area was three districts namely Jalandhar, Gurdaspur and Sangrur of Punjab. The study examined 500 respondents belonging to BPL sections. The Percentage and Chi-square was applied to derive the conclusions. The study established that usage was found very low along with frequency. The study recommended to enhance usage of these services with attractive products and alluring benefits after making them financially literate.
\end{abstract}

KEYWORDS: Bank account, usage, withdrawal, deposit, insurance and remittances.

Article Received: 10 August 2020, Revised: 25 October 2020, Accepted: 18 November 2020

\subsection{INTRODUCTION}

The extent of usage of financial inclusion initiatives via bank account is of paramount importance as access does not always leads to usage. People have banking facilities in their reach but they are not utilizing them due to one reason or the other. In Punjab, basic bank account is opened for everyone and made available as a part of RBI's directions of Financial Inclusion drive. However, the actual success of financial inclusion initiatives can be measured through usage of bank accounts and other banking services.

Having a bank account for a family unit is first step in getting into the overlay of formal financial framework. But it doesn't produce income in itself, rather could be considered best as an empowering factor. The significant angle here is analyzing the utilization of opened accounts for specific purpose and frequency. It is a known fact that the vast majority of the family units open accounts just to receive Government transfers such as MGNREGA wages, Self Help Groups advantages or Government credits.

In this study, usage is measured in terms of withdrawals, deposits, insurance and remittances and for availing loan. Moreover, the chapter examines the factors influencing the usage of these banking services by BPL households of Punjab. The chapter begins by investigating the extent of usage in terms of frequency of savings, deposits, withdrawals and ATM use by the respondents. The objective and hypothesis is given as follows:

- $\quad$ To empirically investigate the actual usage of financial inclusion products and services

$H_{0}$ : There is no significant difference in the usage of zero balance accounts across the districts

In order to test the hypothesis, Chi-square Test has been employed to test the association between categorical data.

\subsection{Extent of Usage of Banking Services}

RBI has specific guidelines regarding dormant accounts. As per RBI's guidelines Para 5.5 Unclaimed Deposits and Inoperative/ Dormant Accounts that a savings / current account will be classified as dormant / inoperative if there are no transactions in the account for over a period of two years.

So, the account is viewed as operative if the account holder kept on executing through the account including saving, depositing, withdrawing and repaying loan etc.

Table 1.1Extent of Savings of BPL families of Punjab

\begin{tabular}{|c|c|c|c|c|c|c|}
\hline & \multicolumn{3}{|c|}{ District } & \multirow[b]{2}{*}{ Total } & \multirow[b]{2}{*}{$\begin{array}{c}\text { Chi-square } \\
\text { (p-value) }\end{array}$} \\
\hline & & Jalandhar & Sangrur & Gurdaspur & & \\
\hline \multirow{7}{*}{ Frequency } & \multirow[b]{2}{*}{ Never } & 95 & 67 & 35 & 197 & 26.287 \\
\hline & & $(42.4)$ & (39.9) & $(32.4)$ & (39.4) & $\left(.001^{*}\right)$ \\
\hline & \multirow{2}{*}{ Weekly } & 45 & 31 & 8 & 84 & \\
\hline & & (20.1) & (18.5) & $(7.4)$ & (16.8) & \\
\hline & \multirow{2}{*}{ Monthly } & 54 & 41 & 46 & 141 & \\
\hline & & $(24.1)$ & (24.4) & (42.6) & $(28.2)$ & \\
\hline & Six Monthly & 13 & 5 & 8 & 26 & \\
\hline
\end{tabular}




\begin{tabular}{|l|c|c|c|c|} 
and annually & $(5.8)$ & $(03)$ & $(7.4)$ & $(5.2)$ \\
\hline \multirow{2}{*}{ Need Based } & 17 & 24 & 11 & 52 \\
\cline { 2 - 5 } & $(7.6)$ & $(14.3)$ & $(10.2)$ & $(10.4)$ \\
\hline \multirow{2}{*}{ Total } & 224 & 168 & 108 & 500 \\
\cline { 2 - 5 } & 100 & 100 & 100 & 100 \\
\hline
\end{tabular}

Note: Values in brackets are percentages

Source: Compiled from survey data

Table 1.1 illustrates the frequency of savings among BPL families of Punjab. Before contemplating the extent of utilization of accounts for availing different types of financial services, it is essential to look at the recurrence of savings among respondents. When money is not saved, neither it can be deposited and nor can be withdrawn and no ATMuse be dreamt of. Jalandhar has 42.4percent respondents who have never saved any money, followed by Sangrur with 39.9 percent and Gurdaspur having 32.4 percent respondents. There are different types of time periods for which they reported savings. Gurdaspur, Jalandhar and Sangrur have monthly saving plans of people by 42.6 percent, by 24.1 percent and 24.4 percent

respectively as people receive salary or wages after one month. Further, 20 percent households in Jalandhar and18.5 percent in Sangrur saved on weekly basis. Weekly savings have been basically reported by daily wagers and shopkeepers. Overall, only five percent people reported six monthly and annual saving plans. Need base choice have been revealed by 10.4 percent respondents. The differences are significant between the districts confirmed by Chisquare as p-value $(.001 *)<.05$. Hence, it can be concluded that saving patterns in all the three districts with respect to different categories are different from each other.

Table 1.2 Frequencies of Deposits and Withdrawals

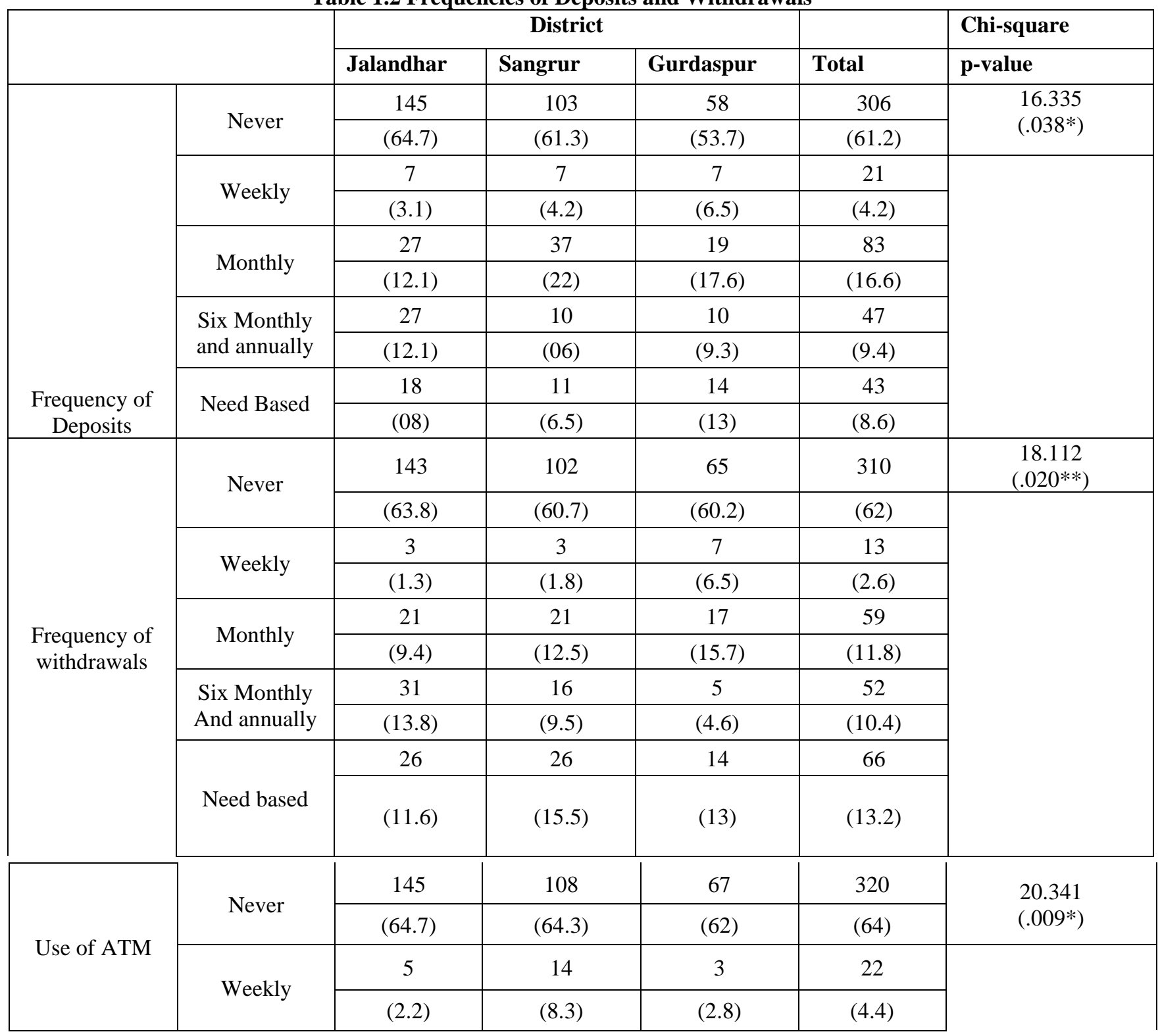




\begin{tabular}{|c|c|c|c|c|c|}
\hline \multirow{2}{*}{ Monthly } & 15 & 13 & 15 & 43 \\
\cline { 2 - 5 } & $(6.7)$ & $(7.7)$ & $(13.9)$ & $(8.6)$ \\
\cline { 2 - 5 } & \multirow{2}{*}{$\begin{array}{c}\text { Six Monthly } \\
\text { and annually }\end{array}$} & 14 & 13 & 3 & 30 \\
\cline { 2 - 5 } & \multirow{2}{*}{ Need Based } & $45.2)$ & $(7.7)$ & $(2.8)$ & $(06)$ \\
\cline { 2 - 5 } & \multirow{2}{*}{ Total } & $20.1)$ & $(11.9)$ & $(18.5)$ & $(17)$ \\
\cline { 2 - 5 } & $(100)$ & $(100)$ & 108 & 500 \\
\hline
\end{tabular}

Note: Values in the brackets are percentages

Source: Compiled from survey data

Table 1.2 discloses the frequency of different financial services such as deposits, withdrawals and ATM use etc. by the BPL respondents of Punjab. The frequency of deposit is a very significant factor that can determine the success and failure of any financial network. Around 61 percent respondents revealed that they had never deposited money in bank. It means larger proportion of people is showing lack of interest in deposits and banking facilities. Nearly 40 percent of BPL families deposited within different time intervals. In Jalandhar district 12 percent of respondents reported monthly and six monthly and annually as most preferred intervals of deposits. In Sangrur, 22 percent interviewees deposited on monthly basis. Around 17 percent households in Gurdaspur district favoured monthly deposits. Overall monthly deposits are the most preferred option.
Withdrawal is also viewed as a proxy for usage of financial inclusion services. As people withdraw, they add money to circulation, which contributes to economic activities. In Jalandhar, 13.8 percent had chosen to withdraw money after six months and annually. Gurdaspur has 15.7 percent and Sangrurhas 12.5percent residents who reported monthly withdrawals. Overall, a significant proportion of 62 percent respondents had reported that they never withdrew money.

ATM use is also an important factor. As people use ATM to withdraw, they add money to circulation; which helps the economic system. Overall, 64 percent interviewees reported that they have never used ATM. Only 17 percent examinees are using it as and when required.

Table 1.3 Evaluation of Usage for other Financial Services

\begin{tabular}{|c|c|c|c|c|c|c|}
\hline \multirow[b]{2}{*}{ Indicators } & \multirow[b]{2}{*}{ Categories } & \multicolumn{3}{|c|}{ District } & \multirow[b]{2}{*}{ Total } & \multirow{2}{*}{$\begin{array}{l}\text { Chi-square } \\
\text { p-value }\end{array}$} \\
\hline & & Jalandhar & Sangrur & Gurdaspur & & \\
\hline \multirow{4}{*}{$\begin{array}{l}\text { Availed any } \\
\text { loan }\end{array}$} & \multirow[t]{2}{*}{ No } & 131 & 77 & 59 & 267 & $\begin{array}{c}6.256 \\
\left(.044^{*}\right)\end{array}$ \\
\hline & & $(58.5)$ & $(45.8)$ & $(54.6)$ & $(53.4)$ & \\
\hline & \multirow{2}{*}{ Yes } & 93 & 91 & 49 & 233 & \\
\hline & & $(41.5)$ & $(54.2)$ & $(45.4)$ & $(46.6)$ & \\
\hline \multirow{6}{*}{$\begin{array}{c}\text { Sources of } \\
\text { availing loan }\end{array}$} & \multirow[t]{2}{*}{$\begin{array}{l}\text { Not availed any } \\
\text { loan }\end{array}$} & 131 & 77 & 59 & 267 & $\begin{array}{l}12.401 \\
\left(.015^{*}\right) \\
\end{array}$ \\
\hline & & $(58.5)$ & $(45.8)$ & $(54.6)$ & $(53.4)$ & \\
\hline & \multirow[t]{2}{*}{ Formal source } & 25 & 18 & 19 & 62 & \\
\hline & & $(11.2)$ & $(10.7)$ & $(17.6)$ & $(12.4)$ & \\
\hline & \multirow[t]{2}{*}{ Informal source } & 68 & 73 & 30 & 171 & \\
\hline & & $(30.4)$ & $(43.5)$ & $(27.8)$ & $(34.2)$ & \\
\hline \multirow{6}{*}{$\begin{array}{l}\text { Reasons for } \\
\text { not availing } \\
\text { loan }\end{array}$} & \multirow[t]{2}{*}{$\begin{array}{l}\text { Procedural } \\
\text { Formalities }\end{array}$} & 35 & 16 & 08 & 59 & $\begin{array}{l}36.815 \\
(.001 *) \\
\end{array}$ \\
\hline & & (15.6) & $(9.5)$ & (7.4) & (11.8) & \\
\hline & \multirow[t]{2}{*}{ No need for loan } & 13 & 09 & 07 & 29 & \\
\hline & & $(5.8)$ & $(5.4)$ & $(6.5)$ & $(5.8)$ & \\
\hline & \multirow{2}{*}{$\begin{array}{l}\text { Need a loan but } \\
\text { worried about } \\
\text { repayment }\end{array}$} & 10 & 16 & 22 & 48 & \\
\hline & & $(4.5)$ & $(9.5)$ & $(20.4)$ & $(9.6)$ & \\
\hline
\end{tabular}




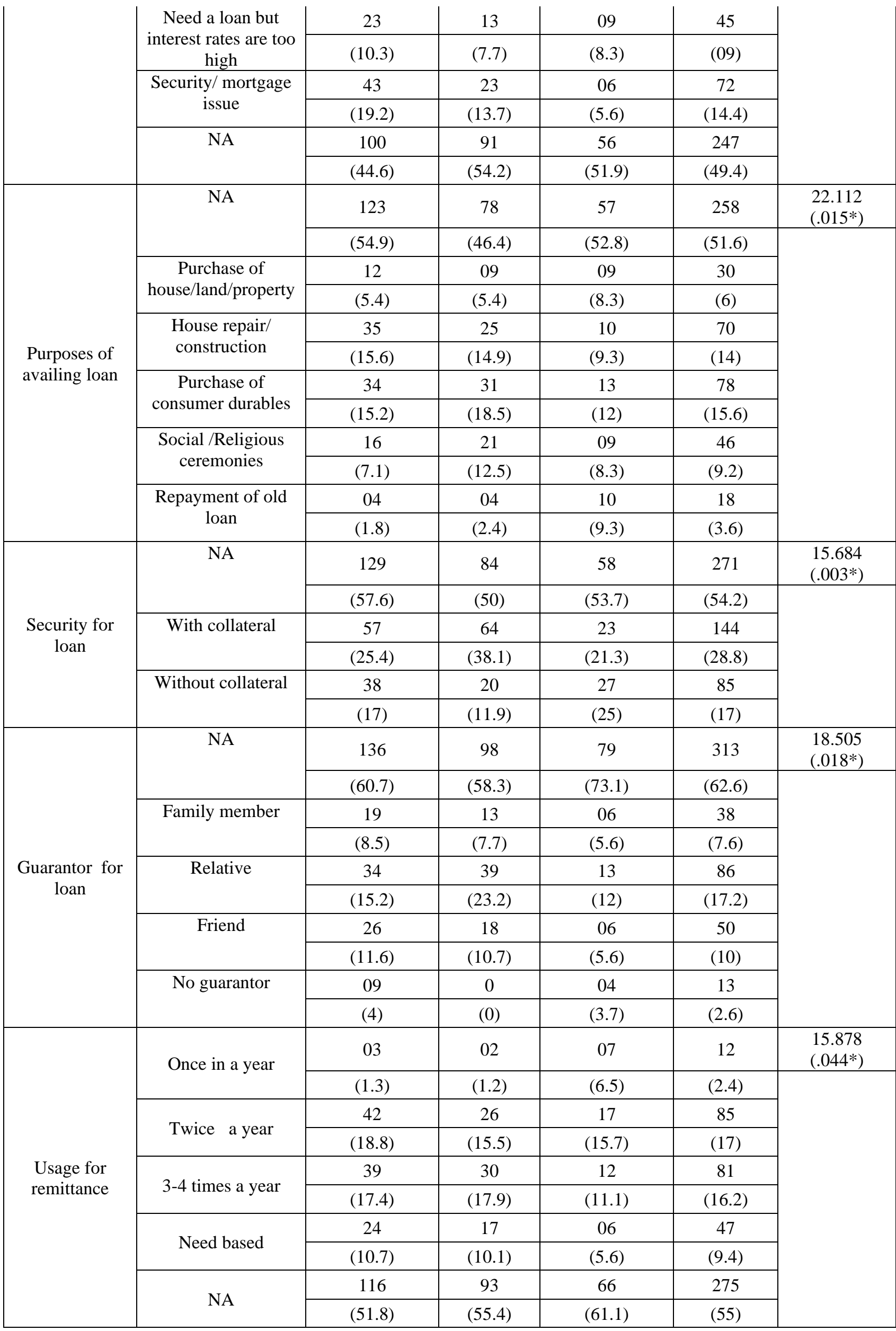




\begin{tabular}{|c|c|c|c|c|c|c|}
\hline $\begin{array}{l}\text { Usage for } \\
\text { insurance }\end{array}$ & No & 49 & 44 & 48 & 141 & $\begin{array}{c}18.836 \\
\left(.0001^{* *}\right)\end{array}$ \\
\cline { 3 - 6 } & \multirow{2}{*}{ Yes } & $(21.9)$ & $(26.2)$ & $(44.4)$ & $(28.2)$ & 359 \\
\cline { 3 - 6 } & & 175 & 124 & 60 & $(71.8)$ \\
\cline { 2 - 6 } & Total & $(78.1)$ & $(73.8)$ & $(55.6)$ & 500 \\
\cline { 2 - 6 } & & 100 & 100 & 108 & 100 \\
\end{tabular}

Note: Values in brackets are percentages

Source: Compiled from survey data

Table 1.3 illustrates the usage of other financial services such as availing loans, remittances and insurance etc alongwith the issues associated with the usage of these services. Borrowing is also an important phenomenon while considering usage of accounts. The proportion of people using accounts for availing loans is very low. Overall 46.6 percent respondents have availed loan. However, only 12.4 percent households have availed loan from formal sources. They have availed loan from a bank, a cooperative society and a non-banking financial institution. A significantproportion of around 34.2 percent has turned to non-formal sources for fulfilling their financial needs. If district wise comparisons are made, Gurdaspur district has highest percentage, i.e., 17.6 percent who are availing loan form formal sources, followed by Jalandhar and Sangrur.

As far as reasons for not availing loan are concerned, almost 14 percent BPL heads have revealed problem of security and mortgage while availing loan. They are of the view that if they can provide security, then why they would take a loan. They can mortgage the propertyand get loan even without any kind of hassle form informal channels. Then another reason advocated for not availing loan is procedural formalities. Around 11.8 percent BPL families have disclosed that paper work is too much while availing loan from formal sources. Further nine percent respondents have revealed that they were worried about repayment and interest rate charged on the amount borrowed.

While enlisting the purposes of availing loan by the respondents, 15.6 percent have revealed the borrowing of money for buying consumer durables such as refrigerator, T.V, water purifiers and two wheelers etc. House repair and construction is also an important purpose for borrowing funds. Almost 14 percent examinees have availed loan for this cause. Even nine percent have used loans for social and religious ceremonies. This kind of use of funds will result in defaulting of loans and failure of spirit of the policy initiated. About three percent have also taken loan to repay the old one.

Provision of security and mortgage of property is a mandate while availing loan. Here 28.8 percent respondents have to offer property as security before borrowing funds. On the contrary, 17 percent availed loan without any collateral. The respondents have revealed that they are even ready to offer their property such as house, small land area or gold but they can't understand procedural formalities and paper work for filing loan application from formal sources. Mostly they get loan with the reference of a friend or a relative. Around 17 percent reported support from friends to get a loan whereas 10 percent took the help of their relatives.

Remittances are also taken into account for examining the usages of accounts opened under the drive. Near about 55 percent BPL households , in all the selected districts have not used their accounts for remittances as they don't know how to do the transactions or they don't have any member residing in other countries or other parts of the country. Remaining 45 percent respondents reported to have transfers from members living abroad or other types of transfers viz once, twice, three to four times a year and as per need. Around17 percent examinee revealed transfers twice, 16.2 percent are getting 3-4 times a year and 9.4 percent arereceiving on the need basis. Households having members abroad are still using these accounts for availing remittance services than other counterparts.

Insurance service is also added under financial services. A significant proportion around 71.8 percent have availed insurance service. But few of them reported that they have taken insurance as agents of companies convinced them to get insurance policy. As a result majority got themselves insured and it resulted in usage of accounts also.

In short, it can be concluded that 39.4 percent respondents don't save at all and around 60 percent neither deposit nor withdraw their money. Major problem here is again vicious circle of poverty. Low income, low savings; which results in low deposits and low withdrawals. The study revealed that 36 percent examinee use ATM, around 46 percent used their accounts for availing loan ,45 percent used for remittances and around 70 percent respondents used for insurance availing services. Mostly they use their accounts to withdraw money transfers under Government schemes. Hence, around 40 percent respondents have reported usage of accounts opened under financial inclusion drive to avail different types of financial services. Actually people are not using these accounts regularly and frequency has also been found very low. A significant percentage has reported banking transaction between six months to twelve months. Overall p-values $(.038 *, .020 *, .009 *, .044 *$, $.015^{*}, .001^{*}, .015^{*}, .003^{*}, .018^{*}$ and $\left..044^{*}\right)<.05$, providing strong evidence against null hypothesis. It can be concluded that difference in usage of zero balance accounts with respect to various financial inclusion services has been found significant between 
the districts. Overall, Gurdaspur district is leading in usage of various facilities though the number is also not big for the districts as compared to the other two districts.

\section{REFERENCES}

Abimbola, A., Olokoyo, F. O., Babalola, O., \& Farouk, E. (2018). Financial Inclusion as a Catalyst for Poverty Reduction in Nigeria. International Journal of Scientific Research and Management, 6(06), 481 - 490.

Ackah, C., \&Acquah, A. (2012). Which households use which financial services? Evidence from Ghana. Institite of Statistical, Social and Economic Research. Retrieved from https://www.econrsa.org/system/files/w orkshops/papers/2012/ackahhouseholds-financial-services.pdf on 23.10.2017

Addury, M. M. (2019). Impact of Financial Inclusion for Welfare: Analyze to Household Level. Journal of Finance and Islamic Banking, 1(2), 90-104.

Adebowale, O., \& Lawson, D. (2018). How does access to formal finance affect household welfare dynamics? Micro evidence from Nigeria. GDI Working Paper 2018-024. Manchester: The University of Manchester.

Adongo, J., \&Deen-Swarray, M. (2006). Poverty alleviation in rural Namibia through improved access to financial services (No. 109). Namibian Economic Policy Research Unit.

Aguera, P. (2015, March). Financial inclusion, growth and poverty reduction. In ECCAS, Regional Conference (pp. 1-19).

Ahmad, M. H., Atiq, Z., Alam, S., \& Butt, M. S. (2006). The impact of demography, growth and public policy on household saving: a case study of Pakistan. Asia Pacific Development Journal, 13(2), 5772.

Ajide, F. (2015). Financial inclusion and rural poverty reduction: Evidence from Nigeria. International Journal of Management Sciences and Humanities, 3(2).

Al-Hussainy, E., Beck, T., Demirguc-Kunt, A., \& Zia, B. (2008). Household use of financial services. World Bank Working Paper, 502-516.

Alfansi, L., \&Sargeant, A. (2000). Market segmentation in the Indonesian banking sector: the relationship between demographics and desired customer benefits. International Journal of Bank Marketing, 18(2), 64 - 74.
Akpandjar, G. M., Quartey, P., \&Abor, J. (2013). Demand for financial services by households in Ghana. International Journal of Social Economics, 40(5), 439-457.

Allen, F., Demirguc-Kunt, A., Klapper, L., \&Peria, M. S. M. (2012). The foundations of financial inclusion: Understanding ownership and use of formal accounts. Policy Research Working Paper Series 6290, The World Bank.

Allen, F., Demirguc-Kunt, A., Klapper, L., \&Peria, M. S. M. (2016). The foundations of financial inclusion: Understanding ownership and use of formal accounts. Journal of Financial Intermediation, 27, 1-30.

Ardic, O. P., Heimann, M., \&Mylenko, N. (2011). Access to financial services and the financial inclusion agenda around the world: a cross-country analysis with a new data set. The World Bank.

Beck, T., Demirgüç-Kunt, A., \&Honohan, P. (2009). Access to financial services: Measurement, impact, and policies. The World Bank Research Observer, 24(1), 119-145.

Birkenmaier, J., \& Fu, Q. (2018). Household financial access and use of alternative financial services in the US: two sides of the same coin?. Social Indicators Research, 139(3), 1169-1185

Campero, A., \& Kaiser, K. (2013). Access to credit: Awareness and use of formal and informal credit institutions (No. 2013-07). Working Papers.

Claessens, S. (2006). Access to financial services: A review of the issues and public policy objectives. The World Bank Research Observer, 21(2), 207-240.

Gitaharie, B. Y., Soelistianingsih, L., \&Djutaharta, T. (2018). Financial inclusion: Household access to credit in Indonesia. Competition and Cooperation in Economics and Business.

Jos, A., George, D., Shivshankar, V., \& Thomas, S. V. (2011). Exploring reasons for dormancy in no frills savings accounts in Tamil Nadu.

Kendall, J., Ponce, A., \&Mylenko, N. (2010). Measuring financial access around the world. The World Bank.

Kostov, P., Arun, T., \&Annim, S. (2015). Access to financial services: The case of the 'Mzansi'account in South Africa. Review of Development Finance, 5(1), 34-42.

Kumar, A., Pal, R., \& Pal, R. (2019). Usage of formal financial services in India: Demand barriers or supply constraints?. Economic Modelling, 80, 244-259.

Kumar, N. (2013). Financial inclusion and its determinants: evidence from India. Journal of Financial Economic Policy, 5, 4 - 19.

Malhotra, N. K. (2002). Marketing research: An applied orientation. New Delhi: Mac Milan Publishing Company. 
Rai, A., \&Saha, A. (2010). Financial inclusion in karnataka: a study of operationalisation of no frills accounts. Paper Presented At 5th Annual Conference on Public Policy at IIM, Bangalore, 8th-11th August 2010.
Ramakrishnan, D. (2012, June). Financial literacy and financial inclusion. In 13th Thinkers and writers Forum.

Roa, M. J. (2015). Financial inclusion in Latin America and the Caribbean: access, usage and quality. CEMLA.

\section{Annexures}

Q1. How regularly do you save?
1).Never
2) Weekly
3)Monthly
4)SixMonthly
5) Need Based

Q2: Have you availed of cheque book facility from thebank?
1)Yes
2)No
3) Noidea

Q3: Do you regularly deposit money in your bank account? What is the frequency of deposits?
1).Never
2) Weekly
3) Monthly
4)SixMonthly
5) NeedBased

Q4:.Do you regularly withdraw money from your account? How often do you withdraw money from your account?
1).Never
2) Weekly
3)Monthly
4) Six Monthly 5) NeedBased

Q5: Do you have an ATM-cum debit card? How often do you use the ATM-cum debit card?
1).Never
2) Weekly
3)Monthly
4)SixMonthly
5) NeedBased

Q6. Have you or any household member ever availed of a loan?
1)Yes
2)No

Q7 .From where was the loan availed of?
1)FormalSource
2) Informalsource
3) NA

Q8. If answer to Q6 is no, why has the household never availed of a loan?
1) No need foraloan
2) Need a loan but worried aboutrepayment

3) Need a loan but interest rates are toohigh

4) Security/mortgageissue 5)ProceduralDifficulties $\quad$ 6)NA

Q9 If answer to Q8 is yes, for what purpose was the loan availed of?
1) Purchaseofhouse/land/Property
2) Houserepair/construction
3) Purchase ofconsumer durables
4) Social/Religious ceremonies
5) Repayment ofoldloan
6) NA 
Q10. How was the loan extended to you or any household member?

$\begin{array}{lll}\text { 1)Withcollateral } & \text { 2)Withoutcollateral } & \text { 3)NA }\end{array}$

Q11. If the loan was extended to you or any household member against collateral, what was the collateral?
1)Land
2)House
3)Gold
4)NA

Q12. Was there a guarantor for the loan?

$\begin{array}{llll}\text { 1)FamilyMember } & \text { 2)Relative } & \text { 3)Friend } & \text { 4)No Guarantor }\end{array}$

Q13.Did you or any household member receive money transfers from family members Living outside the household/ or othertransfers?
1) Once inayear
2) Twiceinyear
3)Thrice inayear
4) NeedBased

5)NA

Q14 In what form did the household receive money?
1) Postal
2) Moneyorder
3) Bankaccounttransfer
4) Other (Please specify) 5)

NA

Q15. Do you or any household member currently have any kind of insurance?

1)Yes

2)No 